\title{
PEMANFAATAN SEL PUNCA PADA INFARK MIOKARD
}

\author{
Loretta C. Wangko \\ Jan H. Awaloei \\ Janry A. Pangemanan \\ Bagian Jantung dan Pembuluh Darah Fakultas Kedokteran \\ Universitas Sam Ratulangi Manado \\ Email: lorettawangko@yahoo.com
}

\begin{abstract}
World-wide, myocardial infarction and heart failure are still the leading causes of deaths and use up a great deal of money. In myocardial infarction there frequently incur cardiomyocyte injuries. Naturally, resident cardiomyocytes will undergo proliferation and contribute to the increasing and repairing of myocardium post infarction. Unfortunately, this capacity of regeneration is very limited. Moreover, injured cardiomyocytes are replaced by scar tissues. Pharmacotherapy with ACE-Inhibitors and $\beta$ blockers can give some clinical improvement, but can not inhibit the loss of cardiomyocytes. Nowadays, stem cell therapy has proclaimed some promising benefits. Among all the introduced stem cells, mesenchymal stem cells are the most popular since they have the capability to differentiate and then to develop into cardiomyocytes, maintain the myocardial thickness, reduce heart remodeling of the non infarct myocardium, improve heart function, and can be used from allogenic donors. Besides that, these cells are easier to obtain and isolate, are genetically stable, have the capacity for angiogenesis, homing to the injured areas or inflammation, and supplying growth factors and cytokines for tissue repair.
\end{abstract}

Keywords: stem cell, cardiomyocyte, transplantation, donor

\begin{abstract}
Abstrak: Infark miokard dan gagal jantung masih merupakan penyebab kematian utama di dunia dan menyerap biaya pengobatan yang tinggi. Pada infark miokard sering terjadi cedera kardiomiosit. Secara alamiah kardiomiosit residen akan mengalami proliferasi dan mengambil bagian dalam meningkatkan dan memulihkan miokard pasca infark. Kapasitas regenerasi ini sangat terbatas. Selain itu kardiomiosit yang cedera akan digantikan oleh jaringan ikat. Farmakoterapi dengan penghambat ACE dan $\beta$ bloker dapat memberikan perbaikan klinis, tetapi tidak dapat menghambat kehilangan kardiomiosit. Dewasa ini terapi sel punca telah mengumandangkan manfaat yang menjanjikan. Dari berbagai sel punca yang dikemukakan, sel punca mesensimal yang paling diminati oleh karena kemampuannya berdiferensiasi dan berkembang menjadi kardiomiosit, mempertahankan ketebalan miokard, menurunkan remodeling jantung pada bagian yang tidak infark, memperbaiki fungsi jantung. dan dapat diambil dari donor alogenik. Disamping itu, sel-sel ini lebih mudah diperoleh dan diisolasi, stabil secara genetik, berkapasitas angiogenesis, homing ke tempat cedera atau inflamasi, dan memasok growth factors dan sitokin untuk perbaikan jaringan.
\end{abstract}

Kata kunci: sel punca, kardiomiosit, transplantasi, donor

Dewasa ini pengobatan gangguan kardiovaskular telah berkembang pesat. Walaupun demikian secara global infark miokard dan gagal jantung masih tetap merupakan pe- nyebab kematian utama dan menyerap tunjangan kesehatan yang cukup besar. ${ }^{1-4} \mathrm{Di}$ Amerika Serikat gagal jantung mencakup populasi sekitar lima juta dengan 400.000 
kasus baru setiap tahunnya. Sebagai penyebab utama gagal jantung disini adalah infark miokard $^{1,5,6}$ yang ditemukan sekitar 1,1 juta populasi setiap tahunnya. ${ }^{1,3}$

Pada infark miokard terjadi cedera selsel otot jantung (kardiomiosit). Secara alamiah kardiomiosit residen (kardiomiosit yang terdapat di jantung sejak awal) dapat berproliferasi dan berkontribusi dalam peningkatan dan pemulihan massa otot miokard pasca cedera infark. ${ }^{5,7,8} \mathrm{Hal}$ ini membantah paradigma lama yang menyebutkan jantung sebagai post-mitotic organ. ${ }^{9,10}$ Tidak dapat disangkal bahwa kapasitas beregenerasi serta kemampuan mengurangi efek remodeling ventrikel dan mempertahankan fungsi jantung sangat terbatas. Selain itu sebagian kardiomiosit yang cedera akan digantikan oleh jaringan parut. ${ }^{5,7}$

Pengobatan farmakologik antara lain dengan angiotensin converting enzyme inhibitors (ACE-I) dan $\beta$ blockers dapat memperbaiki secara klinis, ${ }^{3,5}$ tetapi tidak sepenuhnya dapat menghambat kehilangan kardiomiosit tersebut. ${ }^{3,5,6}$ Juga tindakan angioplasti dan trombolitik walaupun dapat meringankan penyebab infark tetapi selang waktu antara onset oklusi dan reperfusi sangat menentukan sampai sejauh mana terjadi cedera miokard. Sampai saat ini belum ada pengobatan medikamentosa ataupun prosedur pengobatan lainnya yang dapat menggantikan parut miokard dengan jaringan kontraktil yang fungsional. ${ }^{3}$ Hal ini akan memengaruhi pemulihan fungsi jantung dan mempermudah terjadinya remodeling jantung. $5,6,11$

Dalam hal infark miokard dan gagal jantung pemulihan fungsi jantung menjadi masalah yang masih sulit diatasi. Selain secara farmakologik, pengobatan lainnya seperti penggunaan cardiac assist devices, ventricular resynchronization therapy, surgical cardiomyoplasty dan transplantasi jantung masih sangat terbatas. ${ }^{2}$ Dewasa ini salah satu prosedur pengobatan yang sangat menjanjikan adalah penggunaan sel punca untuk menggantikan kehilangan kardiomiosit tersebut dan memacu neovaskularisasi. ${ }^{4,6}$

\section{SEL PUNCA DAN TRANSPLANTASI}

Sel punca merupakan sel-sel yang belum berdiferensiasi penuh, dapat berproliferasi, berpotensi self-renewal, yang kemudian berdiferensiasi menjadi satu atau lebih jenis sel khusus (termasuk kardiomiosit) sebagai respons terhadap stimuli sinyal yang sesuai (sifat plastisitas). ${ }^{5,6,10,12}$ Sel punca yang ditransplantasi akan mengalami proses homing (mudik ke jaringan/ organ tertentu) dimana mereka tertarik ke tempat cedera. Hal ini mungkin berhubungan dengan faktor lingkungan mikro (microenvironment) yang diperlukan untuk pertumbuhan dan berfungsinya sel-sel tersebut. Selain itu integrin dan molekul adhesi, homing receptors, keadaan iskemia dan peningkatan ekspresi vascular endothelial growth factor (VEGF) juga turut berperan. ${ }^{5}$ Terjadinya fusi antara sel-sel hasil transplan dan kardiomiosit residen sangat dibutuhkan untuk keberhasilan tercapainya fungsi jantung yang optimal. ${ }^{10}$

Pada hakekatnya mekanisme genetik dan selular dari tansplantasi sel punca masih banyak yang belum dipahami. ${ }^{5,6,13}$ Pemilihan jenis sel punca, penentuan waktu yang tepat dan jalur transplantasi, serta cara meningkatkan kemampuan sel-sel tersebut masih memerlukan pemahaman yang lebih detail. ${ }^{6}$ Tidak disangsikan pengunaan biomolekuler berteknologi tinggi sangat diperlukan untuk menunjang keberhasilan transplantasi sel punca pada infark miokard. Sangat diharapkan di masa depan transplantasi sel punca dapat dioptimalkan untuk menjamin pemulihan fungsi jantung pasca infark miokard.

\section{JENIS-JENIS SEL PUNCA}

Terdapat beberapa jenis sel punca yang telah diteliti untuk diaplikasikan sebagai bakal kardiomiosit, yaitu:

\section{Sel punca embrionik (sel punca fetal, embryonic stem cells, ES cells)}

Kelompok sel ini merupakan populasi 
sel yang paling primitif (berpotensi omnipoten). Sel-sel ini diambil dari inner cell mass blastosist berusia lima hari setelah fertilisasi, yang terdiri dari $100 \mathrm{sel},{ }^{6,12}$ dan mampu menghasilkan tiga lapisan germinal embrionik. ${ }^{3,12,14}$ Pada isolasi dan kultur media yang sesuai, sel-sel ini dapat bereplikasi, berpotensi self-renewal, dan tetap mempertahankan kapasitas berdiferensiasi ke sel-sel khusus, termasuk kardiomiosit. Penggunaan sel punca ini dengan menggunakan jaringan manusia baik untuk tujuan reproduksi maupun terapeutik masih mengundang berbagai perdebatan ilmiah, etis, moral, dan politik. ${ }^{9}$

\section{Sel punca mesensimal dewasa (adult mes- senchymal stem cells/MSCs)}

Sel-sel ini berasal dari sumsum tulang atau organ lain, dan secara in vitro mempunyai kapasitas diferensiasi multilineage (Gambar 1). ${ }^{3,8,15}$ Bone marrow stromal cells (BMSCs) merupakan kelompok sel-sel stroma sumsum tulang yang menyusun populasi heterogen dari sel-sel jaringan ikat. ${ }^{9}$ Sel-sel dengan penanda $\mathrm{CD} 34^{+}$merupakan prekursor sel-sel darah dan endotel, sedangkan yang CD34- sebagai sel punca mesensimal. ${ }^{9,13}$ Dalam keadaan normal selsel ini inaktif. Tanpa memandang sumber asalnya, sel-sel ini mengekspresikan molekul permukaan tertentu sesuai dengan lingkungan mikronya. ${ }^{13}$ Di dalam kultur, sel ini dapat tetap tidak berdiferensiasi dan mempertahankan fenotip yang stabil untuk beberapa generasi. Sebagai kontroversi terdapat kesulitan untuk menentukan fenotip yang pasti dan tidak tersedianya penanda untuk menyeleksi populasi sel murni. Hasil studi yang menggunakan MSCs, adipose progenitor cells dan multipotent adult progenitor cells (MAPCs) memperlihatkan bahwa sel-sel yang dihasilkan melalui berbagai metode berbeda ternyata tidak memperlihatkan penanda yang berbeda. ${ }^{13}$

\section{Sel punca hemapoietik dewasa/sel pro- genitor}

Terdapat dua jenis sel punca di dalam sumsum tulang. Jenis pertama yang menghasilkan seluruh sistem hemapoietik jangka panjang (hematopoietic stem cells /HSCs), jarang ditemukan $(1: 10.000$ sel sumsum tulang), berpotensi self-renewal dan berdiferensiasi menjadi sel progenitor yang lebih dewasa dalam sumsum tulang. Jenis kedua yaitu sel progenitor dengan kapasitas terbatas untuk self-renewal dan diferensiasi, dan hanya dapat mempertahankan hematopoiesis selama dua bulan (jangka pendek). ${ }^{3} \mathrm{Ma}-$ sih tetap diperdebatkan apakah sel-sel transplantasi sumsum tulang dapat bermanfaat mencegah remodeling ventrikel dan memperbaiki gagal jantung kongestif, ${ }^{11}$ terlebih lagi untuk jangka panjang yaitu lebih dari 12 bulan berhubung hasil studi yang masih bervariasi dan jumlah sampel yang terbatas. $^{4,16}$

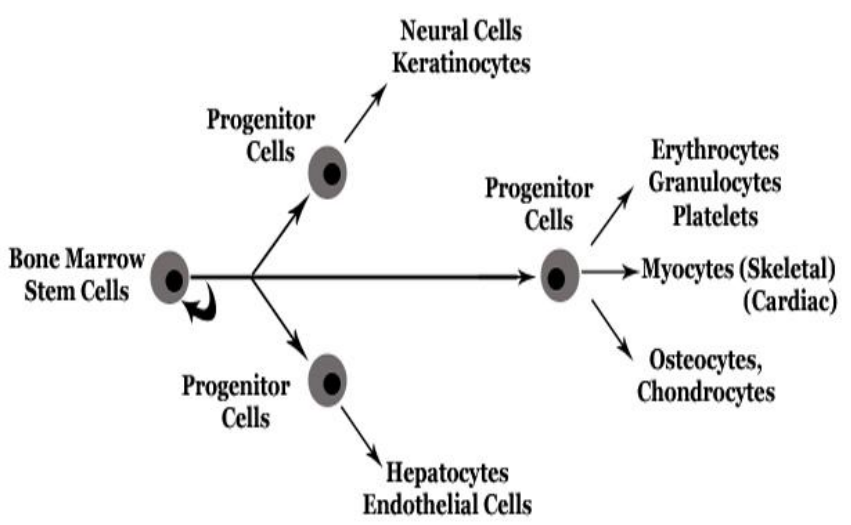

Gambar 1. Pola perkembangan transdiferensiasi BMSC dewasa menjadi berbagai jenis galur sel (multiple lineages). Sumber Orlic, 2002. ${ }^{2}$

\section{DASAR PENGGUNAAN SEL PUNCA DALAM PENGOBATAN}

Sel punca mempunyai dua sifat dasar, yaitu kemampuan berdiferensiasi menjadi berbagai jenis sel dan kemampuan memperbaharui dirinya (self-renewal). Dalam penerapan terapi sel punca, sel-sel yang akan digunakan harus dapat berdiferensiasi menjadi jenis sel yang sesuai dengan jaringan/organ target. ${ }^{6,8,9}$ Sel punca embrionik berkemampuan omnipoten, dimana dapat berdiferensiasi menjadi ketiga jenis lapisan germinal, sedangkan sel punca nonembrionik/dewasa masih dapat berdiferen- 
siasi tetapi terbatas menjadi beberapa jenis jaringan tertentu (multipoten). ${ }^{9}$ Sel punca embrionik digalakan untuk tissue enginering karena sel-sel ini tetap mempertahankan kemampuan bermitosis dan merupakan sumber sel yang stabil. ${ }^{9}$

Terdapat tiga mekanisme dasar yang harus dipenuhi dalam terapi sel punca pada infark miokard: dapat berdiferensiasi menjadi kardiomiosit, berfusi dengan kardiomiosit residen, dan mempunyai efek parakrin (cell-to-cell, cell talk). ${ }^{2}$ Penggunaan terapi sel punca pada gangguan jantung masih memerlukan berbagai pertimbangan menyangkut seleksi sel punca yang terbaik, serta waktu dan jalur transplantasi oleh karena hal-hal ini sangat menentukan keberhasilan transplantasi. ${ }^{6}$

Pada infark miokard, sel punca yang ditransplantasi harus memenuhi tiga mekanisme yaitu:

1. Trafficking sel punca. Iskemia miokard menginduksi pembentukan sitokin, reseptor yang larut dan molekul adhesi, yang mengakibatkan mobilisasi berbagai sel punca dari sumsum tulang, seperti sel punca mesensimal, sel punca hemapoietik dan endothelial progenitor cells ke tempat cedera melalui proses homing. Pada infark miokard akut, sitokin yang diproduksi antara lain stromal derived factor $-1 \alpha$ (SDF-1 $\alpha$ ), tenascin $C$, fibronectin, vascular adhesion molecule-1 (VCAM-1), laminin dan vascular endothelial growth factor (VEGF), yang berperan untuk mobilisasi berbagai sel punca sumsum tulang. Bahan-bahan ini melepaskan protease yang memecah molekul adhesi dan membantu sel-sel punca terlepas dari matriks sumsum tulang. Diperlukan mobilisasi sel yang cukup unuk mendapatkan efek terapeutik yang bermakna. Untuk membantu tercapainya hal di atas, dapat juga ditambahkan granulocyte colony-stimulating factor (G-CSF) yang meningkatkan pelepasan matrix metallloproteinase-9, neutrophil elastase, dan cathepsin G. Protease ini memecah molekul adhesi di dalam stroma sumsum tulang dan memfasilitasi mobilisasi hemapoietic stem cells (HSCs). Pendekatan secara farmakologik dengan menggunakan VCAM dan intracellular adhesion molecule (ICAM-1) untuk memobilisasi HSCs belum memuaskan. Secara alamiah produksi endogen bahan-bahan ini tidak memberi hasil yang diinginkan sehingga mobilisasi sel-sel tersebut harus dilipat gandakan untuk memperoleh efek terapi yang bermakna. ${ }^{6}$

2. Diferensiasi menjadi kardiomiosit. Sekitar satu minggu pasca infark, jantung manusia memperlihatkan peningkatan jumlah miosit yang bermitosis pada daerah perbatasan iskemia. Sumber prekursor kardiomiosit dapat berasal dari sel punca residen jantung dan sel punca sirkulasi yang mengadakan homing ke jantung pasca infark. Mekanisme sinyaling termasuk G-CSF dan jagged-1 protein dengan mengubah lingkungan mikro miokard menstimulasi sel punca untuk berdiferensiasi. Fibroblas jantung dan kardiomiosit dewasa pada zone perbatasan iskemi dapat membentuk kardiomiosit baru dalam jumlah yang sangat terbatas. Reperfusi pasca iskemia meningkatkan transkripsi aktin otot polos yang bertanggung jawab untuk diferensiasi fibroblas jantung menjadi miofibroblas. $^{2}$ Walaupun sel punca berdiferensiasi menjadi kardiomiogenik, masih tetap diragukan apakah selsel ini dapat berpartisipasi dalam unit kontraktil miokard oleh karena mereka terpisah dari kardiomiosit residen oleh jaringan ikat. Fusi sel-sel tersebut sangat penting untuk regenerasi dan terjaminnya coupling elektromekanik yang baik pasca infark. ${ }^{2}$

3. Efek parakrin. Sel-sel punca yang berhasil ditanam ke dalam miokard tetap mengalami kematian nonapoptosis. Oleh karena masa hidup yang pendek, maka efek parakrinpun berlangsung singkat. Secara umum efek parakrin bertujuan mengaktivasi sel punca jantung residen dan menyelamatkan kardiomiosit yang malfungsi di daerah 
infark. ${ }^{2}$ Sel punca tersebut menghambat apoptosis kardiomiosit, meningkatkan angiogenesis, menyelamatkan miosit yang cedera dan menghambat remodeling patologik melalui produksi sitokin lokal dan growth factor yang bereaksi secara autokrin atau parakrin. Tumor necrosis factor- $\alpha$ (TNF $\alpha$ ) memproteksi kardiomiosit terhadap cedera hipoksia. VEGF meningkatkan angiogenesis pada perbatasan iskemia. Cardiotrophin-1 berefek proteksi terhadap kematian sel noniskemik. Insulin-like growth factor-1, oncostatin, tumor necrosis factor- $\beta$, interleukin- $1 \alpha$ (IL$1 \alpha)$ dan IL-6 memperpanjang hidup miosit. Sel punca transplan mengubah matriks ekstrasel dan mempromosi remodeling dengan cara menurunkan produksi kolagen tipe I, III, tissue inhibitor dari metalloproteinase 1; hal ini bertentangan dengan efek fibroblas jantung yang memperlihatkan overekspresi kolagen, protein matriks, dan metalloproteinase.

\section{PENDEKATAN SECARA KARDIO- MIOPLASTI SELULAR}

Hilangnya kardiomiosit setelah infark miokard serta tidak adanya mekanisme pemulihan endogen merupakan penyebab terjadinya progresivitas gagal jantung. Remodeling ventrikel yang patologik diakibatkan oleh tergantinya miokard cedera oleh jaringan parut, yang tersusun oleh matriks ekstrasel. Matriks ini dihasilkan oleh sel non miositik, yang berakibat terjadinya disfungsi ventrikel. ${ }^{13}$

Jantung dewasa diduga mengandung subpopulasi kardiomiosit yang tidak berdiferensiasi penuh; sel-sel ini akan memasuki siklus sel dan bermitosis setelah terjadinya infark miokard. Pendapat lain mengatakan bahwa kardiomiosit dewasa hampir tidak dapat beregenerasi sehingga peran sel punca residen jantung dalam perbaikan infark sangat minimal dan tidak mencukupi. $^{5,8,13}$

Untuk menggantikan sel yang cedera atau memicu regenerasi kardiomiosit mela- lui transplantasi sel dapat diperoleh dengan cara: 1) transplantasi sel punca yang berdiferensiasi menjadi kardiomiosit atau meningkatkan angiogenesis; 2) mobilisasi sel punca residen sumsum tulang ke tempat cedera dengan menggunakan sitokin (granulocyte colony-stimulating factor/GCSF dan stem-cell factor); dan 3) pengobatan lokal dengan growth factors, antara lain insulin-like growth factor dan hepatocyte growth factor yang menginduksi diferensiasi sel progenitor jantung menjadi kardiomiosit. ${ }^{5,8}$

Sel punca atau sel prekursor jaringan imatur dapat berproliferasi, berpotensi untuk self-renewal, dan berdiferensiasi menjadi satu atau lebih jenis sel khusus, termasuk kardiomiosit. ${ }^{5,8}$ Mekanisme selular dan genetik yang memicu transdiferensiasi sel punca masih sangat kurang dipahami. Sel transplan akan mengalami proses homing dimana mereka tertarik ke tempat cedera. Mekanisme homing dan sinyal diferensiasi yang khas organ tertentu untuk sel punca juga tidak jelas dipahami. Diduga berkaitan dengan faktor lingkungan mikro yang menguntungkan pertumbuhan sel punca, integrin dan molekul adhesi lainnya, homing receptors, iskemia, dan peningkatan ekspresi VEGF. ${ }^{5}$

Strategi pendekatan kardiomioplasti lainnya melibatkan pendekatan tak langsung. Pada hewan coba (murine) sel punca sumsum tulang yang dimobilisasi dengan pemicu suntikan sitokin (GCSF dan stem cell factor) yang ditujukan ke infark miokard, dapat bereplikasi, berdiferensiasi, dan menunjang perbaikan miokard serta meningkatkan fungsi jantung. Dalam hal kardiomioplasti selular dapat digunakan growth factors seperti insulin like growth factor dan hepatocyte growth factor untuk menarik sel progenitor jantung, menginduksi diferensiasi menjadi kardiomiosit, dan untuk promosi replikasi. Insuline like growth factor juga berefek untuk proteksi kematian kardiomiosit dan mengurangi terjadinya remodeling ventrikel kiri pada hewan coba. ${ }^{5}$

Untuk mengoptimalkan aplikasi klinis, proliferasi sel punca harus segera, dapat bertahan, dan menyiapkan coupling sel baru 
yang efektif dan fungsional. Proses ini harus berlangsung pada saat miokard masih dapat mempertahankan fungsi memompakan darah dan perfusi jaringan. Kesemuanya ini juga tergantung pada keserentakan dengan pembentukan struktur vaskular yang optimal. ${ }^{5}$

\section{SEL DONOR}

Penentuan sel donor yang ideal untuk infark miokard masih diperdebatkan baik secara ilmiah, etis, moral, maupun politik. ${ }^{5,17}$ Sel donor tersebut harus dapat menggantikan miokard yang nekrotik dan meminimalkan remodeling. Selanjutnya akan dibahas jenis-jenis sel donor serta keuntungan dan kerugiannya.

\section{Kardiomiosit fetal}

Pada hewan coba telah dibuktikan transplantasi kardiomiosit fetal dapat bertahan hidup, berproliferasi, dan membentuk diskus interkalaris dengan miokard residen. Transplantasi pada jaringan parut dapat membentuk jaringan otot jantung yang baru dan memperbaiki fungsi jantung. Selain itu transplantasi tersebut dapat mengurangi dilatasi ventrikel, penipisan infark, dan disfungsi otot jantung. Kardiomiosit fetal juga berperan dalam pelepasan faktor kardioprotektif seperti vascular endothelial growth factor (VEGF) melalui jalur parakrin yang merangsang pembentukan pembuluh darah baru. Hal ini akan meningkatkan perfusi dan membersihkan debris infark miokard. ${ }^{5}$

\section{Mioblas otot skelet}

Terdiri dari sel prekursor miogenik/sel satelit yang dalam keadaan normal inaktif. Pada keadaan cedera sel-sel ini secara cepat dimobilisasi, berproliferasi dan berdiferensiasi untuk menggantikan miosit skeletal yang cedera. ${ }^{6}$ Sebagai sel prekursor, jenis sel ini dapat mengalami mitosis, berproliferasi, serta membentuk sinsitium dan miosit otot skelet baru. Untuk pengunaan transplantasi autologus sel-sel ini cukup ideal karena mudah diperoleh melalui biopsi otot sendiri, dapat dikembalikan lagi setelah di- perbanyak secara in vitro, tahan terhadap iskemia dan tidak menyandang konsekuensi imunologik dan etik. Perbaikan miokard tergantung dari jumlah mioblas yang dimasukkan. Potensi untuk pemberian intravaskular menyebabkan sel-sel ini tampaknya merupakan pilihan sel donor. ${ }^{5,6}$ Kerugiannya yaitu mioblas skeletal tidak sepenuhnya berdiferensasi menjadi kardiomiosit, tidak adanya koneksi elektromekanik antara kardiomiosit residen dan myotube hasil diferensiasi mioblas skeletal sehingga dapat menjadi sumber aritmia. ${ }^{6}$

\section{Endothelial progenitor cells (EPCs)}

Neovaskularisasi sangat dibutuhkan un-tuk mempertahankan kelangsungan hidup kardiomiosit baru. EPCs merupakan sel residen dalam sumsum tulang yang dilepaskan ke dalam sirkulasi setelah terjadi infark miokard akut dan dapat menghasilkan neovaskularisasi pada dewasa. Sel-sel ini merupakan donor yang ideal oleh karena bersifat autologus sehingga tidak mememerlukan imunosupresi. Pada pemberian EPCs dan GCSF, sel-sel yang bermigrasi ke daerah infark dalam 48 jam akan mengalami transdiferensiasi menjadi sel endotel dan menginduksi neovaskularisasi. Sel-sel ini juga membatasi terjadinya apoptosis kardiomiosit yang hipertrofi di sekitar daerah infark dan remodeling ventrikel, serta memperbaiki fungsi jantung hewan coba pasca infark. Salah satu kendala adalah terbatasnya jumlah sel yang dapat dipanen dari pasien. Cara memperbanyak jumlah EPCs ex vivo telah dikembangkan, akan tetapi peningkatan jumlah EPCs akan menekan kapasitas homing dan mengurangi efektivitas. Pemberian statin pada penderita koroner meningkatkan proporsi EPCs sirkulasi. Sel-sel sumsum tulang autologus menyekresi faktor angiogenik seperti VEGF dan macrophage chemoattractant protein-1 (MCP-1) yang menstimulasi proliferasi sel endotel dan meningkatkan perfusi kolateral dan fungsi jantung. ${ }^{5}$

\section{Sel punca embrionik}

Sel-sel ini merupakan sel omnipoten 
yang dapat berdiferensiasi menjadi semua jenis sel dalam tubuh, termasuk kardiomiosit. Kemampuan sel-sel ini pada manusia lebih kecil dari pada tikus. Transplantasi sel-sel ini sangat bermanfaat karena imunoreaktif yang minimal serta terjaminnya fungsi mekanoelektrik antara transplan dan sel residen. ${ }^{10}$ Aplikasi sel punca ini untuk studi klinis masih sangat terbatas karena terbatasnya ketersediaannya, berpotensi terjadi tumor ${ }^{10}$ serta masalah etis, agama dan politik yang belum terpecahkan. 5,6,10,17

\section{Sel punca mesensimal dewasa}

Bersifat omnipoten, autologus, dan dapat diperoleh dari sumsum tulang dan darah tepi, ${ }^{5}$ serta jaringan lainnya. ${ }^{13}$ Sel-sel ini dapat berdiferensiasi menjadi sel-sel jaringan khusus termasuk kardiomiosit, sel endotel dan sel otot polos. ${ }^{5,13}$ Pemakaian sel punca ini baik yang autologus maupun alogenik ternyata tidak memerlukan imunosupresi. Sel-sel yang diimplantasi setelah infark miokard dapat berdiferensiasi menjadi kardiomiosit, mempertahankan ketebalan dinding, menurunkan remodeling ventrikel dari bagian noninfark, dan memperbaiki fungsi jantung. ${ }^{5,10}$ Selain itu sel-sel ini menyekresi sitokin angiogenik yang memperbaiki pemulihan aliran kolateral pada hewan coba. ${ }^{10}$ Sel punca mesensimal ditemukan sekitar 0,001-0,01\% dari sel mononuklear dalam sumsum tulang, ${ }^{13}$ dan sudah dapat dikultur. Keunggulannya dibandingkan sel lainnya adalah lebih mudah diperoleh dan diisolasi, potensi dapat diperbanyak cukup tinggi, stabil secara genetik, dapat diproduksi dari isolat ke isolat lainnya, kompatibel dengan prinsip tissue enginering, dan berpotensi untuk meningkatkan perbaikan berbagai jaringan vital. Juga sel-sel ini berpotensi multinucleage, serta telah cukup banyak studi yang dilakukan. Sel fibroblastik sumsum tulang, umumnya disebut BMSCs, merupakan sel stroma multipoten (Gambar 1). ${ }^{13}$ Secara in vitro BMSCs telah berhasil dikultur menjadi kardiomiosit. Selain itu diduga bone marow-derived cells melepaskan faktor-faktor yang memicu angiogenesis, proteksi kardiomiosit dari apoptosis, serta menginduksi proliferasi dan rekrut kardiomiosit endogen. ${ }^{9}$ Telah diteliti pada hewan coba penggunaan adipose-derived MSCs ternyata dapat menurunkan apoptosis dan meningkatkan angiogenesis pada kokultur dengan kardiomiosit, dan juga berkemampuan untuk berdiferensiasi menjadi kardiomiosit. ${ }^{2}$ Pada hewan coba (domba) telah diperlihatkan kemampuan sel punca manusia berdiferensiasi secara khas untuk jaringannya menjadi fenotip kardiomiosit yang fungsional. Transplantasi alogenik mungkin dapat digunakan untuk aplikasi klinis karena kurangnya efek imunogenisitas dan relatif mudah dikultur. ${ }^{13}$ Pemakaian sel punca alogenik sangat menguntungkan karena donor dapat dipilih secara lebih bebas, berkualitas dan diuji untuk berbagai organisme. ${ }^{13}$ Juga dikenal sel progenitor mesodermal atau sel progenitor dewasa yang multipoten. Sel-sel ini berproliferasi luas dan berdiferensiasi secara in vitro menjadi sel-sel ke tiga lapisan germinal. ${ }^{3}$

\section{CARA MELAKUKAN TRANSPLAN- TASI SEL PUNCA}

Transplantasi sel punca dapat dilakukan melalui beberapa cara: Transvaskular (infus arteri intrakoroner dan infus intravena) dan injeksi langsung ke dinding ventrikel (injeksi transendokardium, transepikardium dan trans vena koronaria) ${ }^{10}$

\section{Transvaskular}

\section{Infus arteri intrakoroner}

Dengan menggunakan percutaneous transluminal coronary catheter sel-sel punca sumsum tulang dimasukkan melalui arteri koronaria dan dapat mencapai konsentrasi maksimum di daerah infark dan sekitarnya. ${ }^{5,10}$ Sel-sel dapat melakukan homing pada daerah yang berbatasan dengan infark secara homogen.

\section{Penyuntikan intravena}

Cara ini praktis dan disukai karena tidak memerlukan tindakan operasi atau kateterisasi. Hal ini bisa dilaksanakan bila sel punca mempunyai mekanisme homing yang 
efektif, sehingga sel-sel ini dapat terkumpul di daerah infark. Faktor lingkungan mikro, ekspresi matriks dan molekul adhesi oleh jaringan yang cedera, homing receptors dan berbagai faktor yang berkaitan dengan migrasi diduga terlibat dalam mekanisme homing. Walaupun demikian adanya homing sel-sel ini ke organ lainnya dapat membatasi jumlah sel yang mencapai daerah infark. ${ }^{5,10}$

\section{Injeksi langsung ke dinding ventrikel pada tepi daerah infark}

Cara ini menggunakan lebih sedikit sel untuk memperoleh implan dibandingkan pemberian intrakoroner dan intravena. Prosedur intra dan pasca operasi cukup beresiko dengan angka keberhasilan pada hewan coba $40 \%$. Juga dapat dilakukan implantasi sel dengan menggunakan percutaneous catheter-based myocardial injection dituntun oleh maping elektromekanik. ${ }^{5}$ Masalah yang perlu dipertimbangkan yaitu terbentuknya pulau-pulau sel pada jaringan infark, yang dapat mengakibatkan ketidakstabilan elektrik dan tercetusnya takiaritmia ventrikel. $^{5,10}$

\section{Injeksi transendokardium}

Injeksi dilakukan melalui valvula aorta dan ditujukan ke permukaan endokardium ventrikel kiri. ${ }^{10}$

\section{Injeksi transepikardium}

Cara ini digunakan sebagai penyerta dalam coronary artery bypass grafting (CABG). Dapat dilakukan bersama-sama pada operasi jantung terbuka. ${ }^{10}$

\section{Injeksi trans vena koronaria}

Dengan menggunakan jarum serta dituntun ultrasound sel transplan BMCs dimasukkan melalui vena koronaria sejajar dengan dinding ventrikel ke dalam miokard yang cedera pada hewan coba. ${ }^{10}$

\section{BAHASAN}

Masih banyak pertanyaan mendasar mengenai aplikasi sel punca yang belum dipahami. Sel donor pilihan yang optimal dan jumlah sel punca yang ditransplantasi belum disepakati. Traverse (2010) dalam penelitian TIME mengadakan transplantasi sel punca sumsum tulang mononuklear autologus pada pasien STEMI (ST-elevation myocardial infarction) anterior yang luas. Pada setiap pasien diberikan 100 juta sel pada 3-10 hari setelah PCI. Pada studi di Eropa REPAIR-AMI pemberian sel berbeda-beda jumlahnya dimana terdapat sejumlah pasien yang menerima sampai tiga kali lipat dari lainnya. ${ }^{18}$ Perlu dipahami bahwa sel punca dewasa terbatas jumlahnya sehingga sulit diisolasi dan dimurnikan. ${ }^{5}$

Mengenai waktu pemberian transplantasi juga belum disepakati. ${ }^{5,13}$ Secara rasional, manfaat terbesar bila transplantasi dilakukan sedini mungkin setelah terjadi infark miokard akut. Jadi sebelum terjadinya fase remodeling ventrikel atau stadium akhir kardiomiopati iskemik. Perlu diingat puncak proses inflamasi pada hari-hari pertama setelah infark mungkin dapat mengganggu transplantasi, sedangkan transplantasi dua minggu setelah terbentuk jaringan parut infark kurang bermanfaat. Berpatokan pada hal-hal tersebut maka transplantasi sel antara hari ke-7 dan 14 setelah infark yang paling dapat diterima. ${ }^{5}$

Mengenai cara pemberian transplantasi yang ideal juga belum disepakati. ${ }^{5,13} \mathrm{Ke}$ mampuan hidup dan berfungsinya sel punca jangka panjang juga belum jelas. Strategi pemberian bersama-sama angioblas mungkin berefek sinergis dan dapat meningkatkan perfusi ke daerah iskemi kronis yang telah ada dan ke daerah sel punca. ${ }^{5}$

Data transplantasi sel punca masih sangat terbatas karena umumnya masih dilakukan di laboratorium dengan menggunakan hewan coba. Apakah transplantasi sel punca ini berpotensi untuk menggantikan miokard yang cedera pada pasien dan mencegah terjadinya gagal jantung, dan selanjutnya diaplikasikan ke populasi pasien pasca infark masih memerlukan penelitian lanjut. ${ }^{5}$ Selain itu sel punca tersebut harus dapat berdiferensiasi menjadi kardiomiosit, sel otot polos dan sel endotel vaskuler untuk menjamin vaskularisasi yang cukup.,12

Selain hal-hal di atas, keamanan meru- 
pakan masalah yang perlu diperhatikan. Sel implan dapat berdiferensiasi menjadi fibroblas, dan bukan miosit, yang akan menambah pembentukan jaringan parut, menekan fungsi jantung, dan memicu aritmia yang membahayakan kehidupan. Sel-sel yang tidak terintegrasi ke dalam miokardium akan mempengaruhi konduksi listrik dan kontraksi sinsitial dari jantung. Terjadinya tumor seperti teratoma berkaitan dengan pemakaian sel punca embrionik. Dan konsekuensi jangka panjang pada penggunaan seluruh populasi sel sumsum tulang mononuklear, dengan berbagai sel punca khusus organ, dapat menghasilkan jaringan non kardia.

\section{SIMPULAN}

Pemanfaatan transplantasi sel punca pada infark miokard masih menghadapi banyak persoalan. Meskipun demikian hasilhasil yang dicapai dalam transplantasi sel punca yang dapat membuat regenerasi miokard, kiranya dapat menjadi model terapi yang layak dilakukan dan bermanfaat dalam mencegah remodeling ventrikel dan memperbaiki gagal jantung dewasa yang ada. Sel punca mesensimal merupakan sel donor yang paling diminati karena dapat berdiferensiasi menjadi kardiomiosit, dapat digunakan yang alogen serta pemberiannya secara sistematik. Selain itu sel-sel tersebut berkemampuan neoangiogenesis (sel endotel dan sel otot polos) untuk menjamin perfusi yang optimal, melakukan homing ke tempat cedera atau inflamasi serta memasok growth factor dan sitokin untuk perbaikan jaringan.

\section{DAFTAR PUSTAKA}

1. The National Institutes of Health Resource for Stem Cell Research. Stem cell information: Can stem cells repair a damaged heart? 2009 [cited 2010 Sept 16]. Available from: http://www.stem cells.nih.gov/info/scireport/chapter9

2. Novotny NM, Ray R, Markel TA, Crisostomo PR, Wang $M$, Wang $Y$ et al. Stem cell therapy in myocardial repair and remodeling. J Am Coll Surg. 2008;207(3):423-30.
3. Orlic D, Hill JM, Arai AE. Stem cells for myocardial regeneration. Circ Res. 2002;91:1092-1102.

4. Zhang C, Sun A, Zhang S, Yao K, Wu C, Fu $M$ et al. Efficacy and safety of intracoronary autologous bone marrowderived cell transplantation in patients with acute myocardial infarction: Insights from randomized controlled trials with 12 or more months follow-up. Clin. Cardiol. 2010;33(6):353-60.

5. Lee M, Makkar RR. Stem-cell transplantation in myocardial infarction: A status report. Ann Intern Med. 2004;140:729-37.

6. Wang $\mathbf{Q}$, Sjoquist $\mathbf{P}$. Myocardial regeneration with stem cells: Pharmacological possibilities for efficacy enhancement. Pharmacological Research 2006;53:331340.

7. Gartner LP, Hiatt JL. Color Textbook of Histology (Third Edition). Philadelphia: Saunders Elsevier, 2007.

8. Forrester JS, Price MJ, Makkar RR. Stem cell repair of infarcted myocardium: An overview for clinicians. Circulation. 2003;108:1139-45.

9. Bajada S, Mazakova I, Richardson JB, Ashammakhi N. Updates on stem cells and their applications in regenerative medicine. J Tissue Eng Regen Med. 2008;2:169-83.

10. Wollert KC, Drexler H. Clinical applications of stem cells for the heart. Circ Res. 2005;96:151-63.

11. Kaligis RWM. Aplikasi terapi stem cell pada infark miokard akut. CDK. 2006;153:13.

12. Setiawan B. Aplikasi terapeutik sel stem embrionik pada berbagai penyakit degeneratif. CDK. 2006;153:5-7.

13. Pittenger MF, Martin BJ. Mesenchymal stem cells and their potential as cardiac therapeutics. Circ Res. 2004;95:9-20.

14. Saputra V. Dasar-dasar stem cell dan potensi aplikasinya dalam ilmu kedokteran. CDK. 2006;153:21-25.

15. Mescher A. Junqueira's Basic Histology (Twelfth Edition). New York: McGrawHill Education, 2010.

16. Arnesen H, Lunde K, Aakhus S, Forfang K. Cell therapy in myocardial infarction. Lancet. 2007;369:2142-43.

17. Nelson TJ, Martinez-Fernandez A, Yamada S, Perez-Terzic C, Ikeda Y, Terzic A. Repair of acute myocardial 
infarction by human stemness factors induced pluripotent stem cells. Circulation. 2009;120:408-16.

18. Traverse JH, McKenna DH, Harvey $\mathrm{K}$, Jorgenso BC, Olson RE, Lesser JR. et al. Results of a phase 1, randomized, double-blind, placebo-controlled trial of bone marrow mononuclear stem cell administration in patients following STelevation myocardial infarction. Am Heart J. 2010;160:428-434. 